\title{
POTENTIAL OF REDUCTION IN THE EMISSION OF METHANE AND NITROUS OXIDE FROM SWINE WASTEWATER AFTER TREATED BY TWO DIFFERENT SYSTEMS
}

Doi:http://dx.doi.org/10.1590/1809-4430-Eng.Agric.v36n6p1198-1205/2016

\section{KELES R. A. INOUE ${ }^{1 *}$, CECÍLIA DE F. SOUZA², ANTONIO T. MATOS ${ }^{3}$, MARILÚ S. SOUSA ${ }^{4}$, MARIA DE F. A. VIEIRA ${ }^{5}$}

${ }^{1 *}$ Corresponding author. Instituto de Terras e Colonização de Roraima/ Boa Vista - RR, Brasil. E-mail: kelesregina@ hotmail.com

\begin{abstract}
Swine wastewater have high pollution load, requiring treatment before its disposal into the environment. Methane $\left(\mathrm{CH}_{4}\right)$ potentially emitted for such waste is considered 21 times more polluting than Carbon dioxide $\left(\mathrm{CO}_{2}\right)$, and the nitrous oxide $\left(\mathrm{N}_{2} \mathrm{O}\right)$ is considered 310 times. In this way, projects of the Clean Development Mechanism (CDM) and energy use related to the $\mathrm{CH}_{4}$ are worldwide diffused. It was evaluated the potential greenhouse gas emissions in the influent and effluent from digesters and stabilization ponds used to treat the swine wastewaters in two commercial farms operating in full cycle, located in the municipality of Oratorios-MG, Brazil. Using the methodology "AM0006" to estimate the average potential of greenhouse gases, it was identified $55 \%$ and $23 \%$ of reduction in emissions from digesters and stabilization ponds, respectively. Thus, when comparing the two systems, in the conditions that they were operated, it can be concluded that the digestion treatment system was more suitable for the treatment of swine wastewater, when taking into account only the emission of the mentioned gases, subjects of this study.
\end{abstract}

KEYWORDS: greenhouse gases, air pollution, swine, waste management.

\section{INTRODUCTION}

In livestock farming, pig farming is an activity that stands out for the number of jobs generated by its high productivity in small areas. It has as main feature the concentration of animals, as well as short time production compared with other cultures. The activity aims at serving the domestic and foreign markets (SERAFIM \& GUIMARÃES FILHO, 2012; SILVA \& BASSI, 2012).

The growth of the sector also generated an increase in waste production, that have high polluting power, making this productive sector been considered of high environmental impact, bringing risks of water and soil pollution, affecting air quality in producing regions, due to the issue of bad odors and uncontrolled proliferation of insects, causing much environmental discomfort to population (NASCIMENTO \& RODRIGUES, 2012).

Air pollution is associated with the problem of the unpleasant odor of waste and emission of polluting gases into the atmosphere. Methane $\left(\mathrm{CH}_{4}\right)$ is a major greenhouse gas $(\mathrm{GHG})$ and animals are major emitters of this gas to the atmosphere through their waste and also by breathing (BARBOSA \& LANGER, 2011).

The GHGs bring major concern because of its lifetime in the atmosphere and its global warming potential compared to $\mathrm{CO}_{2}\left(\mathrm{CO}_{2}\right.$ is the main greenhouse gas, so it was chosen as index 1 to global warming, and other gases are compared to it) (ORRICO JÚNIOR et al., 2009).

The treatment of animal waste is a technological alternative to reduce GHGs and mitigate possible effects on global climate change. So it integrates the strategies of Agriculture Program Low Carbon (ALC), coordinated by the Ministry of Agriculture, Livestock and Supply (MAPA).

\footnotetext{
${ }^{2}$ Universidade Federal de Viçosa/Viçosa - MG, Brasil.

${ }^{3}$ Universidade Federal de Minas Gerais/Belo Horizonte - MG, Brasil.

${ }^{4}$ EMVZ / Universidade Federal do Tocantins/Araguaína - TO, Brasil.

${ }^{5}$ Universidade Federal Rural da Amazônia, Paragominas - PA, Brasil.

Received in: 8-26-2014

Accepted in: 6-1-2016
} 
The objective of this program is to treat 4.4 million cubic meters of waste from pig farming and other activities, to stop the release of 6.9 million tons of $\mathrm{CO}_{2 \mathrm{eq}}$ in the atmosphere (SILVEIRA, 2012).

The CDM projects result in Certified Emission Reductions (CERs), measured in tons of $\mathrm{CO}_{2 \mathrm{eq}}$ called "carbon credits", this metric unit is due to the degrading intensity of each pollutant on the ozone layer. The main greenhouse gases $(\mathrm{GHG})$, in the Brazilian environment are the carbon dioxide (70\% significance) with Global Warming Potential (GWP) equal 1, the methane (19\%) with 21 GWP; and the nitrous oxide (12\%) a GWP value of 310 (OLIVEIRA, 2009).

The treatment of effluent from pig farming contributes to sustainable socioeconomic development by reducing emissions of greenhouse gases to the atmosphere, in addition to improving the quality of surface and groundwater due to the treatment of effluents (OLIVEIRA et al., 2012). There are several forms of treatment of such wastes that can be highlighted, including the use of manure chambers, stabilization ponds and digesters.

Considering that, in Brazil, research on GHG emissions from swine manure coming from biological treatment are still scarce and considering that the country is the world's fourth largest producer and the state of Minas Gerais is the fourth in relation to domestic production, it is necessary to intensify studies on the most appropriate ways for the management of pig waste, currently one of the biggest challenges for production units.

In this context, the aim of this research was to reduce the potential GHG emissions from swine wastewater when subjected to two treatment systems.

\section{MATERIAL AND METHODS}

The experiment was conducted in a pig commercial farm located in Oratórios - MG, Mineira Forest Region, from February $29^{\text {th }}$ to April $11^{\text {th }} 2012$. The unit is located at $20^{\circ} 25^{\prime} 05^{\prime \prime} \mathrm{S}$ latitude and $42^{\circ} 48^{\prime} 08^{\prime \prime}$ longitude $\mathrm{W}$; altitude is 430 meters relative to sea level. The climate according to Köppen classification is Cwa (hot, temperate, and rainy, with dry season in the winter and hot summer).

Two farms were used belonging to the same Commercial Production Unit of Pigs, operating in full cycle; both had the same architectural features and were managed similarly with sheds cleaning made three times a week, by scraping and sweeping with the use of water.

The farm A had a herd of 800 matrixes. The sheds have collective boxes with semi-automatic feeders, automatic waterers pacifier type. The interconnected pipes lead the waste by gravity to a junction box and then the wastewaters were conducted by gravity to the treatment units, which are composed of two digesters and two storage ponds.

The digesters used in the property are the Canadian model with hydraulic retention time of 7 days (Figure 1). The biogas produced is used in the property, which is high enough in energy, and its excess is burned.

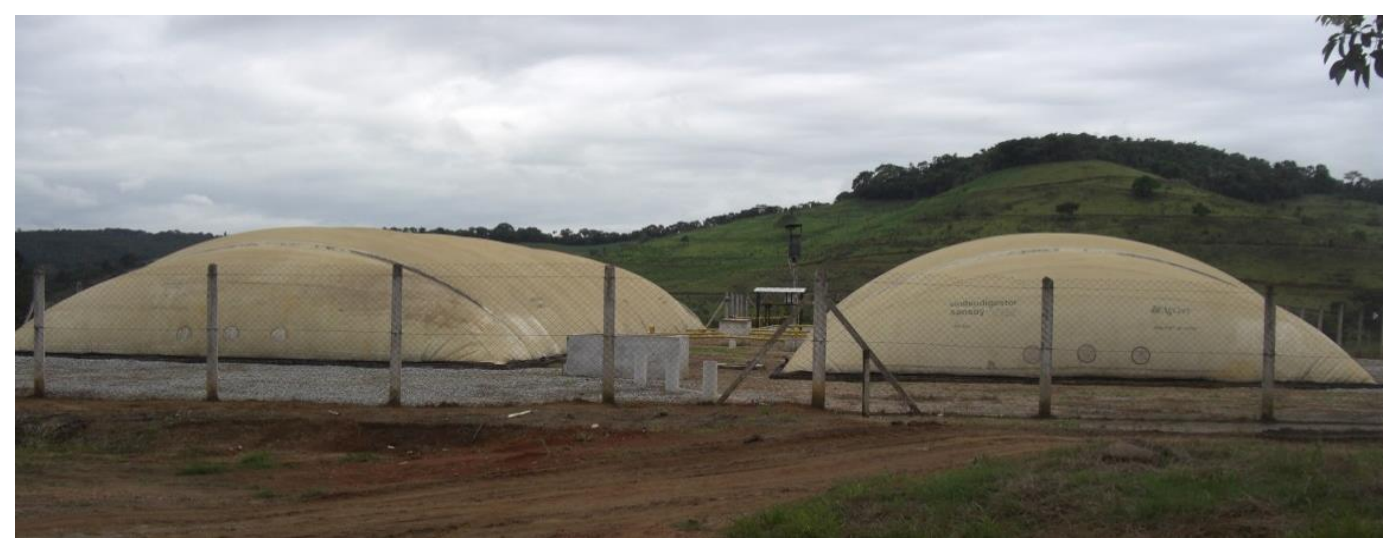

FIGURE 1. External view of the two digesters installed in farm "A". 
Farm B had a herd of 120 matrixes. The sheds had collective stalls with semiautomatic feeders and automatic waterers pacifier type. The interconnected pipes lead the wastewater by gravity to a junction box and subsequently the waste were conducted to the treatment units composed of sequential stabilization, anaerobic, facultative and maturation ponds (Figure 2).

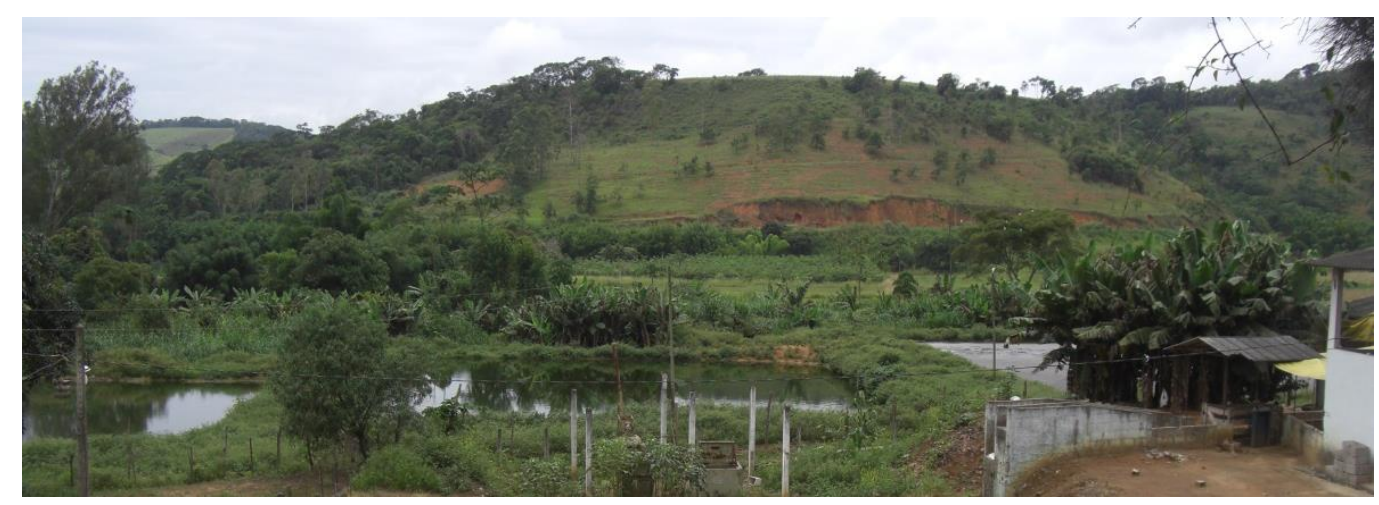

FIGURE 2. External view of anaerobic, facultative and maturation ponds, components of the waste system treatment in farm " $B$ ".

The emissions monitoring in the treatment systems was done through analysis of samples collected on a weekly basis in the influent and effluent treatment systems for seven consecutive weeks. After each collection the samples were identified and immediately led to the Water Quality Laboratory from the Agricultural Engineering Department of UFV for further analysis of the following variables: total nitrogen (N), total solids (TS), and volatile solids (VS), fixed solids (FS). The methods used were nitrogen content, Kjeldahl method with the addition of salicylic acid (MATOS, 2012); total solids (TS), volatile solids (VS), and fixed solids (FS), gravimetric method, following the methodology described in APHA (2005).

The emission of both methane $\left(\mathrm{CH}_{4}\right)$ and nitrous oxide $\left(\mathrm{N}_{2} \mathrm{O}\right)$ was estimated using [eq. (1)], shown in AM0006 methodology "Reduction of greenhouse gas emissions for waste management systems" (UFCCC, 2004) within the Clean Development Mechanism (CDM) established by the Kyoto Protocol:

$$
E_{C H 4}=R S V\left[1-R_{S V}\right] B_{0} D_{C H 4} M C F_{1} G W P_{C H 4} N_{y} 365 \times 1000^{-1}
$$

where,

$\mathrm{E}_{\mathrm{CH} 4}: \mathrm{CH}_{4}$ emission ( $\mathrm{t}$ of $\mathrm{CO}_{2 \mathrm{eq}} \mathrm{yr}^{-1}$ );

$\mathrm{RSV}$ : excretion rate of volatile solids (Animal $\mathrm{kg}^{-1} \mathrm{day}^{-1}$ );

$\mathrm{R}_{\mathrm{Sv}}$ : relative reduction in volatile solids in the considered treatment phase;

$\mathrm{B}_{\mathrm{o}}$ : methane maximum production capacity for manure per animal for a defined population of animals, $\mathrm{m}^{3}$ of $\mathrm{CH}_{4} \mathrm{~kg}^{-1}$;

$\mathrm{D}_{\mathrm{CH} 4}$ : Methane density at $20^{\circ} \mathrm{C}$ temperature and $1 \mathrm{~atm}$ pressure $\left(0.67 \mathrm{~kg} \mathrm{~m}^{-3}\right)$;

$\mathrm{MCF}_{1}$ : Methane conversion factor for waste treatment in the first stage of treatment;

$\mathrm{GWP}_{\mathrm{CH} 4}$ : Global warming potential approved of $\mathrm{CH}_{4}(21)$, and

$\mathrm{Ny}$ - population of animals set for year $\mathrm{y}$.

For $\mathrm{B}_{0}$, biodegradability coefficient that represents the maximum methane production capacity from waste; it used the representative value for Latin America of $0.29 \mathrm{~m}^{3} \mathrm{~kg}^{-1}$. For methane conversion factor (MCF) was used the standard value of 0.1 used for hot climates (IPCC, 2006).

The variable, excretion rate of volatile solids (RSV) was obtained by multiplying the concentration of the VS amount of waste produced per day per animal. The value of Rsv was 
obtained from the results and the concentration of VS in the collected samples in the material (influent and effluent).

The population of animals was defined based on the number of matrix of each farm and the number of animals ready for slaughter per year, which were slaughtered at an average weight of 110 $\mathrm{kg}$. It was used the value of 23 animals ready for slaughter per matrix per year (TALAMINI et al., 2006). The farm A had a herd of 800 matrixes and farm B 120 matrixes. Because of this difference in the number of matrix between farms, for calculation of methane emission, it was decided to admit the that farm B also had 800 matrixes, generating the 18400 value of animals ready for slaughter a year for each farm, thus facilitating the comparison processes of the results and thereof the statistical analysis.

The calculation of nitrous oxide emissions was based on [eq. (2)], presented the same methodology mentioned above;

$$
E_{N 2 O}=G W P_{N 2 O} N R_{E X y}(1-R n) P_{y} E F_{N 20, m m m i} C F_{N 2 O-N, N} 100^{-1}
$$

where,

$\mathrm{E}_{\mathrm{N} 2 \mathrm{O}}$ : Nitrous oxide emissions ( $\mathrm{t}$ of $\left.\mathrm{CO}_{2 \mathrm{eq}} \mathrm{yr}^{-1}\right)$;

$\mathrm{GWP}_{\mathrm{N} 2 \mathrm{O}}$ : global warming potential approved for $\mathrm{N}_{2} \mathrm{O}(310)$;

$\mathrm{NR}_{\mathrm{EXy}}$ : annual average nitrogen excretion rate per animal $\left(\mathrm{kg}\right.$ of $\left.\mathrm{N} \mathrm{Animal}{ }^{-1} \mathrm{yr}^{-1}\right)$;

$\mathrm{Rn}$ : relative reduction of nitrogen in the considered treatment;

Py - population of animals set for the year y;

$\mathrm{EF}_{\mathrm{N} 2 \mathrm{O}, \mathrm{mmmi}}$ : emission factor for the considered stage of the treatment, $\mathrm{kg}$ of $\mathrm{N}-\mathrm{N}_{2} \mathrm{O}$ per $\mathrm{kg}$ of $\mathrm{N}$, and

$\mathrm{CF}_{\mathrm{N} 2 \mathrm{O}-\mathrm{N}, \mathrm{N}}: \mathrm{N}_{2} \mathrm{O}-\mathrm{N}$ conversion factor for $\mathrm{N}(44 / 28)$.

The EF value was used $0.001 \mathrm{~kg}$ of $\mathrm{N}-\mathrm{N}_{2} \mathrm{O} \mathrm{kg} \mathrm{kg}^{-1}$ obtained in IPCC (2006).

The variable nitrogen excretion rate $\left(\mathrm{NR}_{\mathrm{EXy}}\right)$ was obtained by multiplying the concentration of $\mathrm{N}$ by the amount of waste produced per day per animal per year. The value of $\mathrm{Rn}$ was obtained from the results and the concentration of $\mathrm{N}$ in collected samples in the material (influent and effluent), the animal population was defined using the same criteria used in the calculation of methane emissions.

The potential for reduction in the greenhouse emission gases was obtained by the difference between the calculated values for the influent and effluent of both treatment systems used on the farm. The experiment was conducted in randomized block, using two treatments, digester and stabilization ponds, with 7 repetitions (block time).

The characteristics determined in the treatments were evaluated using analysis of variance and the means compared by F test, adopting a level of up to 5\% probability, using SAEG 9.0 software.

\section{RESULTS AND DISCUSSION}

The variables used to obtain the potential reduction in the greenhouse emission gases, based on $\mathrm{t}$ of $\mathrm{CO}_{2 \text { eq }}$, showed great variability (Table 1), even the samples being collected on the same day and time of the week, during the seven collection days.

The waste from the production units of pigs is dependent on the weight and age of the animals. The waste characteristic is also affected by the amount of water used in the cleaning of stalls, as well as the physiology and composition of the formula feed. These characteristics may have influenced the variability of the results, which showed a high standard deviation and coefficient of variation. 
Even with wide variations in their characteristics, knowledge of the composition of the pig wastewater is of fundamental importance in choosing the treatment system to be deployed on the farm (RAMME \& KUNZ, 2009). It has been chosen the most advantageous, both in environmental and economic terms.

The affluent of the treatment systems, showed no significant difference at the level of 5\% probability by $\mathrm{F}$ test. These results are justified, because are raw materials, from two farms managed similarly, indicating that there were no variations significant in the management of the two pig production units.

TABLE 1. Variables evaluated in affluent (A) and effluent (E) of the treatments, digesters and stabilization ponds.

\begin{tabular}{|c|c|c|c|c|c|c|c|c|c|c|c|c|c|c|c|}
\hline & \multirow[b]{2}{*}{ Week } & \multicolumn{2}{|c|}{$\mathbf{N}\left(\mathbf{m g ~ \mathbf { L } ^ { - 1 }}\right)$} & \multicolumn{2}{|c|}{$\mathbf{T S}\left(\mathbf{m g ~ L} \mathbf{L}^{-1}\right)$} & \multicolumn{2}{|c|}{$\mathrm{VS}\left(\mathrm{mg} \mathrm{L}^{-1}\right)$} & \multicolumn{2}{|c|}{$\mathbf{F S}\left(\mathbf{m g ~ L ^ { - 1 }}\right)$} & \multicolumn{2}{|c|}{$\mathrm{ECH}_{4}\left(\mathrm{t} \mathrm{CO}_{2 \mathrm{eq}}\right)$} & \multicolumn{4}{|c|}{$\mathbf{E N}_{2} \mathbf{O}\left(\mathbf{t} \mathbf{C O}_{2 \mathrm{eq}}\right)$} \\
\hline & & $\mathbf{A}$ & $\mathbf{E}$ & $\mathbf{A}$ & $\mathbf{E}$ & $\mathbf{A}$ & $\mathbf{E}$ & $\mathbf{A}$ & E & A & $\mathbf{E}$ & $\begin{array}{c}\% \text { of } \\
\text { reduction }\end{array}$ & A & $\mathbf{E}$ & $\begin{array}{c}\% \text { of } \\
\text { reduction }\end{array}$ \\
\hline \multirow{5}{*}{ Digester } & 1 & 6879.6 & 1999.2 & 43720,00 & 9454.00 & 32623.00 & 5441.00 & 11097.00 & 4013.00 & 838.65 & 139.87 & 83.32 & 157.41 & 11.65 & 88.35 \\
\hline & 2 & 1293.6 & 999.6 & 12386,00 & 10833.00 & 8614.00 & 6972.00 & 3772.00 & 3861.00 & 237.59 & 192.30 & 19.06 & 29.60 & 14.57 & 85.43 \\
\hline & 3 & 1205.4 & 1166.9 & 8695,00 & 7062.00 & 5906.00 & 3819.00 & 2789.00 & 3243.00 & 166.79 & 107.85 & 35.34 & 27.58 & 25.27 & 74.73 \\
\hline & 4 & 3204.6 & 1808.1 & 32636,00 & 8117.00 & 25385.00 & 4223.00 & 7251.00 & 3894.00 & 626.03 & 104.15 & 83.36 & 73.32 & 3.30 & 96.70 \\
\hline & 5 & 1793.4 & 1675.8 & 13949,00 & 9986.00 & 10154.00 & 6395.00 & 3795.00 & 3591.00 & 267.57 & 168.52 & 37.02 & 41.03 & 26.22 & 73.78 \\
\hline \multirow{9}{*}{ Ponds } & 6 & 1793.4 & 1014.3 & 10572,00 & 9771.00 & 7094.00 & 5926.00 & 3478.00 & 3845.00 & 202.80 & 169.41 & 16.46 & 41.03 & 17.45 & 82.55 \\
\hline & 7 & 2116.8 & 1705.2 & 20628,00 & 10371.00 & 15784.00 & 6489.00 & 4844.00 & 3882.00 & 395.69 & 162.67 & 58.89 & 48.43 & 42.03 & 57.97 \\
\hline & 1 & 823.2 & 208.74 & 5060,00 & 1217.63 & 3242.00 & 866.50 & 1818.00 & 1027.00 & 766.79 & 757.33 & 1.23 & 18.84 & 9.42 & 90.58 \\
\hline & 2 & 940.8 & 182.28 & 6866,00 & 1539.25 & 4976.00 & 850.50 & 1890.00 & 1008.75 & 1040.48 & 947.99 & 8.89 & 21.53 & 12.30 & 87.70 \\
\hline & 3 & 1528.8 & 195.51 & 11722,00 & 1406.00 & 8424.00 & 966.63 & 3298.00 & 1152.25 & 1776.35 & 1308.04 & 26.36 & 34.98 & 21.49 & 78.51 \\
\hline & 4 & 980.7 & 194.41 & 2811,00 & 1574.13 & 1788.00 & 986.88 & 1023.00 & 1107.75 & 425.98 & 233.73 & 45.13 & 4.71 & 3.41 & 96.59 \\
\hline & 5 & 1602.3 & 216.83 & 15985,00 & 1966.25 & 11586.00 & 1071.38 & 4399.00 & 1186.50 & 2422.37 & 1907.86 & 21.24 & 36.66 & 19.49 & 80.51 \\
\hline & 6 & 1058.4 & 187.79 & 7557,00 & 1400.00 & 4617.00 & 937.38 & 2940.00 & 1104.00 & 1145.19 & 824.32 & 28.02 & 24.22 & 16.36 & 83.64 \\
\hline & 7 & 2381.4 & 213.89 & 23271,00 & 1722.38 & 17813.00 & 1228.13 & 5458.00 & 1472.75 & 2617.25 & 1862.27 & 28.85 & 54.49 & 40.09 & 59.91 \\
\hline
\end{tabular}

$\mathrm{N}$ - Nitrogen; TS - Total solids; VS - Volatile solids; FS - Fixed solid; $\mathrm{ECH}_{4}$ - Methane emissions (t $\mathrm{Co}_{2 \mathrm{eq}}$ ); $\mathrm{EN}_{2} \mathrm{O}$ - Nitrous Oxide Emissions (t $\mathrm{Co}_{2 \mathrm{eq}}$ ).

For the analyzed variables in the effluent systems treatment there was statistical difference at $5 \%$ probability, by $\mathrm{F}$ test (Table 2 ). The biggest reduction on methane emission potential occurred in the digesters system, the opposite was found for nitrous oxide, with the highest potential reduction in the stabilization pond system.

According to the methodology used, the emission reduction potential is calculated based on the concentration of VS and N present in the affluent and effluent of the treatment systems. Thus, the system that has a higher removal of VS and $\mathrm{N}$ is the one that emits the highest concentration of GHG. The system of stabilization ponds is more efficient in removing VS thus had higher emission potentials when compared with digesters.

TABLE 2. Mean values of $\mathrm{N}, \mathrm{VS}$, and $\mathrm{E}_{\mathrm{CH} 4}$ and $\mathrm{E}_{\mathrm{N} 2 \mathrm{O}}$ in affluent of the treatments evaluated, digesters and stabilization ponds.

\begin{tabular}{cccccc}
\hline Treatments & $\mathrm{N}\left(\mathrm{mg} \mathrm{L}^{-1}\right)$ & $\mathrm{VS}\left(\mathrm{mg} \mathrm{L}^{-1}\right)$ & $\mathrm{E}_{\mathrm{CH} 4}\left(\mathrm{t}\right.$ of $\left.\mathrm{Co}_{2 \mathrm{eq}}\right)$ & $\mathrm{E}_{\mathrm{NO} 2}\left(\mathrm{t}\right.$ of $\left.\mathrm{Co}_{2 \mathrm{eq}}\right)$ \\
\hline Digester & $1481.30 \mathrm{a}$ & $5609.28 \mathrm{a}$ & $149.25 \mathrm{~b}$ & $53.3 \mathrm{a}$ \\
Ponds & $53.97 \mathrm{~b}$ & $0.49 \mathrm{~b}$ & $1120.22 \mathrm{a}$ & $17.50 \quad \mathrm{~b}$ \\
\hline
\end{tabular}

Means followed by different letters in the same column differ at $5 \%$ probability by the $\mathrm{F}$ test.

When taking into consideration the combined emission of these two gases $\left(\mathrm{CH}_{4}\right.$, and $\left.\mathrm{N}_{2} \mathrm{O}\right)$ determined in $\mathrm{t}$ of $\mathrm{CO}_{2 \mathrm{eq}}$ the greater reduction in potential emission occurred in the digester system, obtained 55\%. The stabilization pond system decreased $23 \%$, thus indicating the anaerobic digestion system as more efficient, in the conditions which both systems were operated, reducing 
the potential for greenhouse gas emissions. According to CALATTO \& LANGER (2011), anaerobic digestion is a treatment technology resulting in two products, the bio-fertilizer and the biogas (methane), enabling energy generation, making the farm self-sufficient. It also enables the conversion of methane into carbon credits. In addition to reducing the greenhouse emission gases as evidenced in this study, adding social, environmental and economic values, allowing the sustainability of productive activity.

Among the registered CDM projects in Brazil the sectors that stand out in terms of proposed projects are: renewable energy, with $33 \%$, swine with $25 \%$ and exchange fossil fuel with $18 \%$ (PEREIRA et al., 2009). The swine industry already stands out in this carbon credit market; however, there is still great potential to be explored by the sector, which is of paramount importance the adoption of strategies for publicizing the existence of this mechanism for chain agents, in particular farmers and representatives.

The implementation of anaerobic digestion systems in pig farms has undeniable environmental benefits, significantly reducing the emission of generating greenhouse gases and pollution of natural resources (RIZZONI et al., 2012).

From the $55 \%$ of the potential emission reduction occurred in the anaerobic digestion system, 97.34\% was methane gas and only 2.66 was nitrous oxide. Close values were found in the stabilization pond system, $97.00 \%$ and $3.00 \%$ for methane and nitrous oxide, respectively. But this system has reduced only $23,00 \%$ of GHG in t of $\mathrm{CO}_{2 \mathrm{eq}}$.

These results occurred because the nitrogen concentration in the effluent is less than the concentration of volatile solids, variables used in the equation for the calculation of the potential emission.

To ORRICO JÚNIOR et al. (2011) several factors can interfere with the production of methane, for example, solids concentration, $\mathrm{pH}$, but undoubtedly has the significance of the concentration of volatile solids present in the waste as seen in this study.

ANGONESE et al. (2007) evaluating the potential of equivalent carbon emission reductions in pig unit slaughter using digesters for the primary treatment and a secondary pond for deposit, determined the estimated potential values for methane emissions of 24.26 tons of $\mathrm{CO}_{2 \text { eq }}$ year $^{-1}$. These lower values verified in this study, probably occur due to the volatile solids values used in the calculations. This study was based on the concentration present in the affluent and effluent of wastewater, while those authors used tabulated data along with the weight of local animal in study.

VANOTTI et al. (2008) evaluated the replacement of pig waste treatment system in anaerobic ponds by aerobic systems, found that the emission of nitrous oxide is lower in anaerobic treatment and higher in the aerobic treatment with values of $72.25 \mathrm{t}$ of $\mathrm{CO}_{2 \mathrm{eq}}$ year ${ }^{-1}$ and $109.4 \mathrm{t}$ of $\mathrm{CO}_{2 \mathrm{eq}} \mathrm{yr}^{-1}$, respectively. Lower values than those recorded in this study, probably due to the local conditions of the study, one of the factors that influence the waste characteristics and also to use tabulated data to feed the equation used in the emission calculations.

BORTOLI et al. (2012) stated that the knowledge on $\mathrm{N}_{2} \mathrm{O}$ emissions in biological treatment of effluent is reduced, especially in specific real scale conditions. Thus, presenting large variation in measurement results of production and emission in different condition and process, demonstrating the need for further studies of favorable specific conditions.

After the passage of the effluent treatment system, the emission will be $202.55 \mathrm{t}$ of $\mathrm{CO}_{2 \text { eq }}$ for the process of anaerobic digestion and 1,137.7 $\mathrm{t}$ of $\mathrm{CO}_{2 \mathrm{eq}}$ for the stabilization pond. Based on these values it was possible to calculate the emission per animal year ${ }^{-1}$, for animals kept in sheds connected to digesters this value is $0.01 \mathrm{t}$ of $\mathrm{CO}_{2 \mathrm{eq}}$ animal $^{-1}$ year $^{-1}$ and $0.06 \mathrm{t}_{\text {of }} \mathrm{CO}_{2 \mathrm{eq}}$ animal ${ }^{-1}$ year ${ }^{-}$ ${ }^{1}$ for those housed in sheds connected to stabilization pond. 


\section{CONCLUSIONS}

The highest average potential reduction in methane gases emission and nitrous oxide, based on equivalent carbon dioxide were observed in the anaerobic digestion system. It is $58.2 \%$ more efficient than the stabilization pond system, under operating conditions in which the two systems were evaluated.

It can be inferred that, given the findings and considering the advantages of anaerobic digestion in relation to by-products generated in the process, this system would be an interesting alternative to be considered for the treatment of swine wastewater.

\section{ACKNOWLEDGEMENTS}

The authors thank CAPES and CNPq for the PhD scholarship granted and "INCT Publishing Workshop - CENBAM", especially Noemia Kazue Ishikawa and William Ernest Magnusson, by the contributions to complete this study.

\section{REFERENCES}

ANGONESE, A. R.; CAMPOS, A. T.; WELTER, R. A. Potencial de redução de emissão de equivalente de carbono de uma unidade suinícola com biodigestor. Engenharia Agrícola, Jaboticabal, v.27, n.3, p.648-657, set./dez.2007.

APHA; AWWA; WEF. American Public Health Association; American Water Works Association; Water Environment Federation. Standard methods for the examination of water and wastewater. $21^{\text {th }}$ ed. Washington, D.C, 2005.

BARBOSA, G.; LANGER, M. Uso de biodigestores em propriedades rurais: uma alternativa à sustentabilidade ambiental. Unoesc \& Ciência - ACSA, Joaçaba, v. 2, n. 1, p. 87-96, jan./jun. 2011.

BORTOLI, M.; KUNZ, A.; SOARES, H. M.; BELLI FILHO, P.; COSTA, R. H. R. Emissão de óxido nitroso nos processos de remoção biológica de nitrogênio de efluentes. Engenharia Sanitária e Ambiental, Rio de Janeiro, v.17 n.1, jan./mar. 2012, p. 1-6.

CALATTO, L. \& LANGER, M. Biodigestor - resíduo sólido pecuário para produção de energia. Unoesc \& Ciência - ACET, Joaçaba, v. 2, n. 2, p. 119-128, jul./dez. 2011.

IPCC - Intergovernmental Panel on Climate Change - Guidelines for Greenhouse Gas Inventories 2006 (Revised 1996 IPCC Guidelines for National Greenhouse Gas Inventories).

MATOS, A. T. Qualidade do meio físico ambiental: práticas de laboratório. Viçosa, Ed. UFV, 2012.

NASCIMENTO, R. C.; RODRIGUES, G. S. S. C. Impactos ambientais da suinocultura no município de Uberlândia (MG): possibilidades de sua mitigação por meio do uso de biodigestores. Caminhos de Geografia, Uberlândia v. 13, n. 43, p. 230-243, out. 2012.

OLIVEIRA, R. C. O sistema de trânsito de ônibus rápido (do inglês $B R T$ ) para a cidade de São Paulo. Revista Intertox de Toxicologia, Risco Ambiental e Sociedade, São Paulo, v.2, n.1, fev. 2009.

OLIVEIRA, A. M.; CHAVES, M. C. G. G.; FORMIGO, N. E. M. M. E. O projecto MDL de recuperação de metano de actividadesagro-pecuárias suinícolas Brascarbon. Ecologi@, Lisboa, v.5, p.63-73, 2012.

ORRICO JÚNIOR, M. A. P.; ORRICO, A. C. A.; LUCAS JR. Potencial de produção de biogás remanescente nos efluentes de biodigestores abastecidos com dejetos de suínos, com e sem separação da fração sólida, e conduzidos sob diferentes tempos de retenção hidráulica. Engenharia Agrícola, Jaboticabal, v.29, n.4, p.679-686, out./dez. 2009. 
ORRICO JÚNIOR, M. A. P.; ORRICO, A. C. A.; LUCAS JR. J. Produção animal e o meio ambiente: uma comparação entre potencial de emissão de metano dos dejetos e a quantidade de alimento produzido. Engenharia Agrícola, Jaboticabal, v.31, n.2, p.399-410, mar./abr. 2011.

PEREIRA, S. M.; LOBO, D. S.; ROCHA JR., W. F. Custos e análise de investimento para transporte de dejetos suínos com posterior geração de bioenergia no município de Toledo-PR. Custos e @ gronegócio online, Recife, v. 5, n. 2, mai./ago. 2009.

RAMME, M. A.; KUNZ, A. A utilização de peneiras na separação de fasessólido-líquido em dejetos suínos. Ágora: Revista de Divulgação Científica, Caçador, v. 16, n. 2, 2009.

RIZZONI, L. B.; TOBIAS, A. C. T.; DEL BIANCHI, M.; GARCIA, J. A. D. Biodigestão anaeróbia no tratamento de dejetos de suínos. Revista Científica Eletrônica de Medicina Veterinária, v.9, n.18, jan. 2012.

SERAFIM, G. B.; GUIMARÃES FILHO, L. P. Estudo sobre o reaproveitamento dos dejetos de suínos na bacia do Rio Sangão - Santa Catarina. Revista em Agronegócios e Meio Ambiente, v.5, p. 151-174, out. 2012. Edição Especial.

SILVA, C. L.; BASSI, N. S. S. Análise dos impactos ambientais no Oeste Catarinense e das tecnologias desenvolvidas pela Embrapa Suínos e Aves. Informe Gepec, Toledo, v. 16, n.1, p. 128$143,2012$.

SILVEIRA, M. Tecnologia sustentável: dejetos tratados diminuem emissão de GEE. In: CONFERÊNCIA DAS NAÇÕES UNIDAS SOBRE DESENVOLVIMENTO SUSTENTÁVEL, RIO+20, 2012, Rio de janeiro.

TALAMINI, T J D; MARTINS, F M; ARBOIT, C; WOLOZSYN, N. Custos agregados da produção integrada de suínos nas fases de leitões e de terminação. Custos e @ gronegócio online, Recife, v.2, out. 2006. Edição Especial.

UFCCC - UNITED NATIONS FRAMEWORK CONVENTION ON CLIMATE CHANGE. GHG emission reductions from manure management systems. 2004.

VANOTTI, M. B.; SZOGI, A. A.; VIVES, C. A. Greenhouse gas emission reduction and environmental quality improvement from implementation of aerobic waste treatment systems in swine farms. Waste Management, Oxford, v.28, n.4, p.759-66, 2008. 